\title{
Tumour necrotizing factor- $\alpha$ promoter and GST-T1 genotype predict skin allergy to chromate in cement workers in Taiwan
}

\author{
Bour-Jr Wang ${ }^{1}$, Judith-Sc Shiao ${ }^{2}$, Chiou-Jong Chen ${ }^{3}$, Yeu-Chin Lee ${ }^{4}$ and Yue-Liang Guo ${ }^{4}$ \\ ${ }^{1}$ Department of Environmental and Occupational Health, National Cheng Kung University Medical College, No. 138 \\ Sheng-Li Road, Tainan, 70428, Taiwan, R.O.C., ${ }^{2}$ School of Nursing, National Taiwan University Medical College, \\ No. 1 Jen-Ai Road, Section 1, Taipei, 10051, Taiwan, R.O.C., ${ }^{3}$ Institute for Occupational Safety and Health, \\ Executive Yuan, No. 99 Lane 407, Hengke Road, Sijhih City, Taipei County, 22143, Taiwan, R.O.C., and ${ }^{4}$ Department \\ of Environmental and Occupational Medicine, National Taiwan University (NTU) Medical College and NTU Hospital, \\ No. 17 Syujhou Road, Taipei, 10055, Taiwan, R.O.C.
}

Background: Construction workers exposed to cement are known to suffer from occupational contact dermatitis because of chromate sensitization. It is not clear whether certain genotypes are associated with increased susceptibility of chromate sensitization in those workers regularly exposed to cement.

Objective: The objective of this study was to determine the genotypes predisposing workers to cementinduced contact dermatitis.

Methods: A total of 153 current cement workers who had regular contact with cement were telephone interviewed for skin problems in the past 12 months, work exposure, and personal protection. A dermatologist examined their skin and conducted patch test with common skin allergens. Blood samples were donated for genotypic determination by polymerase chain reaction-based assays for GST-T1, GST-M1 (null/non-null), tumour necrosis factor (TNF) alpha promoter-308G/A, and interleukin (IL) 4-590C/T.

Result: High percentage of dermatitis was noted in the 153 workers examined, which was correlated with reported skin problems. By patch testing, construction workers had a high-prevalence rate $(12 \%)$ of sensitivity to chromate. Sensitivity to chromate was significantly associated with TNF alpha promoter-308 heterozygous (GA) as compared with GG genotype (odds ratio 3.9, 95\% confidence interval 1.1-13.2), as well as with GST-T1 null genotype (odds ratio 5.5, 95\% confidence interval 1.4-36.2), but neither the GST-M1 nor the IL-4 genotypes.

Conclusion: It is concluded that among workers frequently exposed to cement in Southern Taiwan, those with TNF alpha promoter-308 heterozygous (GA) genotype or GST-T1 null genotype had increased risk of chromate sensitization.

Key words: cement workers; chromate sensitivity; contact dermatitis; occupational dermatitis; transepidermal water loss. (c) Blackwell Munksgaard, 2007.

Accepted for publication 27 June 2007

Occupational skin disease, especially contact dermatitis, has been 1 of the most frequently reported disorders among workers regularly contacting with cement $(1,2)$. Skin contact with cement has been associated with irritant contact dermatitis $(3,4)$ and allergic contact dermatitis. The most important allergic agent in cement is soluble hexavalent chromium, or chromate compounds $(5,6)$, followed by metals such as cobalt, ingredients of gloves such as rubber chemicals or latex, epoxy resin, and preservatives. Although the work on modern buildings requiring cement or concrete filling is mostly mechanized or prefabricated and does not involve worker manual handling of cement or cement mixture, fine finishing work on walls, windows, tiles, or bricks requires frequent direct manual manipulation of and contact with cement. Skin contact with cement or its mixtures 
continues to be a problem in this group of workers. In previous study, we found high prevalence of dermatitis, as well as high-sensitization rate to chromate in fine finishing workers in Tainan City, the 4th largest city in Taiwan with a typical urban environment and many construction sites. In this study, we determine the genetic predisposition to dermatitis and sensitization among these workers.

Tumour necrosis factors (TNFs) are potent proinflammatory cytokines, and likely play significant role during contact allergic reactions (7). The gene for TNF is located on chromosome $6 \mathrm{p} 21.1-21.3$ and forms the TNF cluster with the 2-lymphotoxin (LT) genes (LT- $\alpha$ and LT- $\beta$ ) (8). The promoter polymorphism of TNF- $\alpha-308 \mathrm{G}$ to $\mathrm{A}$ has been associated with poly-sensitization to common skin allergenic agents (9). Interleukin (IL)-4 plays an important role in IgE synthesis by activating pre$\mathrm{T}$ helper cells to become Th2 cells that in turn trigger isotype switching from $\operatorname{IgM} / \operatorname{IgG}$ to $\operatorname{IgE}$ in $\mathrm{B}$ cells (10). The IL-4 promoter polymorphism, a C to $\mathrm{T}$ change at position-590, has been reported to be associated with atopy (11). In some studies, IL4-590T allele was associated with higher risk of developing atopy, asthma, and rhinitis in infants (12) as well as with higher total serum IgE (13).

There was some evidence shown that $\mathrm{Cr}^{+6}$ must be reduced to $\mathrm{Cr}^{+3}$, and then it can be bound to skin protein and became a recognized antigen by Langerhans cells (14-16). Glutathione plays a role in the process of reduction $\mathrm{Cr}^{+6}$ to $\mathrm{Cr}^{+3}$ (17). Glutathione transferases (GSTs) may affect the glutathione level in the cell and are involved in the prevention of tissue damage by various oxidative stresses. Glutathione-S-transferase (GST) enzymes conjugate hydrophobic and electrophilic compounds with reduced glutathione to detoxify these chemicals (18). Among the GST enzyme family, genetic polymorphisms on GST-M1 and GST-T1, involving deletion of $20 \mathrm{bp}$, respectively $(19,20)$, result in deficiencies in the enzyme activities. Accumulated evidences have suggested associations between GST-M1 null genotype and various cancers, including smoking-induced lung cancer, bladder cancer, colon cancer, and breast cancer (21-23); and between GST-T1 null genotype and smoking-induced chromosome aberrations (24). Theses genetic polymorphisms are therefore considered important susceptibility markers for environmental toxicants.

\section{Subjects and Methods}

\section{Study subjects}

We have previously studied members of the Cement workers' Association of Tainan City
(25). Telephone interview on medical and occupational history, use and exposure to cement, work activities, protective equipment related to cement, and skin symptoms were obtained. A complete skin examination was conducted for a subset of workers. Skin manifestations were assessed by a dermatologist by symptom questionnaire and physical examination. Photographs of hands were taken during the examination for further review. Dermatitis was diagnosed if erythema, maculopapules, hyperkeratosis, and skin thickening were present. Allergens from European Standard Tray and construction-related substances (Chemotechnique Diagnostic AB, Vellinge City, Sweden; and Trolab, Montreal City, Canada), with a total of 21 substances, were used for patch testing. The testing agents were applied to Finn chambers (Epitest Ltd., Helsinki, Finland), which were fixed to the upper back with Scanpor tape then secured by $3 \mathrm{M}$ tape. The patches were removed after $2 \mathrm{D}$, and the sites were examined for evidence of reaction. The sites were examined again at $3 \mathrm{D}$ by the same dermatologist. The reading at 3D was considered positive if the skin reaction was equal to or greater than erythema and infiltration, with possibly papules and vesicles (26). All subjects signed informed consent before the skin examination. The data were analyzed by descriptive statistics, Student's $t$-test, analysis of variance, and Chi-squared test using sAS package.

\section{Genetic polymorphisms}

Genomic DNA was extracted from blood by standard genomic DNA extraction methods. Screening for genetic polymorphisms of IL-4-590C/T, and TNF- $\alpha-308 \mathrm{G} / \mathrm{A}$ was performed by PCR-RFLP with adequate restriction enzyme, as described in previous studies $(27,28)$. Genetic polymorphism analysis for the GST-M1 and GST-T1 genes was determined simultaneously in a single assay using a multiplex PCR approach based on the method of Arand et al. (29). The DNA sample was amplified with 3 pairs of primers. The PCR produced 3 DNA fragments of $215 \mathrm{bp}$ (GST-M1), 350 bp (albumin), and 480 bp (GST-T1). In both GST-M1 and GST-T1 polymorphisms, gene deletion was responsible for the existence of null alleles. Individuals homozygous with respect to a given null allele lack the respective PCR amplified DNA fragment. Albumin was used as an internal control for the PCR efficiency.

\section{Results}

Table 1 shows the demographic data, the location, and prevalence of dermatitis in a 12 month 
Table 1. Demographic characteristics of successfully examined and genotyped cement workers, Tainan, Taiwan

\begin{tabular}{lcc}
\hline Age & $\begin{array}{l}\text { Male } \\
n(\%)\end{array}$ & $\begin{array}{l}\text { Female } \\
n(\%)\end{array}$ \\
\hline $20-29$ & $12(13.2)$ & $2(3.2)$ \\
$30-39$ & $37(40.7)$ & $21(33.9)$ \\
$40-49$ & $27(29.7)$ & $23(37.1)$ \\
$50-65$ & $15(16.5)$ & $16(25.8)$ \\
Working hour per week & $47.2 \pm 5.5$ & $45.3 \pm 7.3$ \\
Duration of being a cement & $17.6 \pm 9.8$ & $12.9 \pm 9.2$ \\
$\quad$ worker (years) & & \\
Prevalence and involved sites of reported skin diseases \\
in the past 12 months & & \\
Palm & $16(17.6)$ & $5(8.1)$ \\
Fingers & $11(12.1)$ & $2(3.2)$ \\
Sole & $7(7.7)$ & $1(1.6)$ \\
Toe web & $6(6.6)$ & $1(1.6)$ \\
Forearm & $4(4.4)$ & $2(3.2)$ \\
Dorsal hand & $3(3.3)$ & $1(1.6)$ \\
Wrist & $2(2.2)$ & $2(3.2)$ \\
Toe & $3(3.3)$ & $0(0)$ \\
Dermatitis by dermatologist examination & \\
Dorsal fingers & $22(24.2)$ & $8(12.9)$ \\
Dorsal hand & $18(19.8)$ & $9(14.5)$ \\
Volar fingers & $17(18.7)$ & $3(4.8)$ \\
Palm & $15(16.5)$ & $1(1.6)$ \\
Forearm & $9(9.9)$ & $2(3.2)$ \\
Leg & $11(12.1)$ & $1(1.6)$ \\
Back & $6(6.6)$ & $1(1.6)$ \\
\hline & &
\end{tabular}

period, obtained by questionnaire, and location of dermatitis after being examined by a dermatologist. From the 166 cement workers who completed the questionnaire, skin examination, and patch testing, 153 had blood samples available for the genetic study, including 91 men and 62 women.

Prevalence and involved sites of reported skin diseases in the past 12 months showed that palm and dorsa surface of hands were the most prevalent site of involvement, followed by fingers, sole, toe web, and forearm. At the time of skin examination, a high percentage $(39 \%)$ of cement workers was noted to have hand dermatitis.
A high proportion of dichromate sensitization was seen in these workers, followed by mercuric ammonium, nickel, benzalkonium, cobalt, fragrance mix, and phenylmercuric acetate (Table 2). Sensitization to dichromate was associated with reported hand dermatitis in the past 12 months, as well as dorsal hand and forearm dermatitis by examination. Sensitization to cobalt also was associated with dorsal hand dermatitis.

Genotype frequencies at the TNF- $\alpha-308$, IL4-590, GST-T1, and GST-M1 are shown in Table 3. For TNF- $\alpha-308$ and IL-4-590, genotype frequencies were compatible with the Hardy-Weinberg equilibrium with $P$-values $>0.05$.

Table 4 shows the risk factors for skin sensitization to patch test agents in cement workers. Mutually adjusted odds ratios of sex and each genetic polymorphism indicated that male sex, TNF- $\alpha-308$ GA genotype, and GST-T1 null genotype were associated with increased risk for skin sensitization to chromate. Female sex was associated with risk of sensitization to nickel. The rest of the comparisons did not show significant relationship between sex, genotypes, and patch agent sensitization.

\section{Discussion}

Among Taiwanese construction workers, an important causal agent for dermatitis was chromium in cement, as indicated by high prevalence of dermatitis, high percentage of positive skin test to chromium, and a relationship between skin test results and reported and observed skin conditions (Table 2). We found in this study that TNF- $\alpha-308$ GA genotype and GST-T1 null genotype were associated with increased risk for skin sensitization to chromate.

The male construction workers had more skin problems than the female workers, likely because of specific jobs males did, and the infrequent use

Table 2. Skin sensitization in cement workers to test agents, and association of the sensitization with clinical presentation of skin problems

\begin{tabular}{llllll}
\hline & Testing compound & Concentration \% $(w / w)$ & Vehicle & $\begin{array}{c}n(\%) \text { sensitized } \\
\text { in 153 workers }\end{array}$ & $\begin{array}{c}\text { Association with } \\
\text { clinical disease }^{\mathrm{b}}\end{array}$ \\
\hline 1 & Potassium dichromate & 0.5 & Pet. & $19(12.4 \%)$ & A, C, D \\
14 & Mercuric Ammonium & 1.0 & Pet. & $9(5.9 \%)$ & \\
4 & Nickel sulfate & 5.0 & Pet. & $9(5.9 \%)$ & \\
18 & Benzalkonium chloride & 0.1 & Aq. & $7(4.6 \%)$ & C \\
3 & Cobalt chloride & 1.0 & Pet. & $6(3.9 \%)$ & \\
12 & Fragrance mix & 8.0 & Pet. & $6(3.9 \%)$ & \\
17 & Phenylmercuric acetate & 0.01 & Aq. & $4(2.6 \%)$ & \\
\hline
\end{tabular}

Pet., petrolatum; Aq., aqueous.

${ }^{a}$ Thimerosal, Captan, Nitrofurazone, Copper sulfate, Epoxy Resins, Balsam of Peru, Carba mix, Thiuram Mix, Colophony, Black Rubber Mix, Kathon CG, Benzyl peroxide, Formaldehyde, and Mercapto Mix had less than 3 subjects sensitized.

${ }^{\mathrm{b}} \mathrm{A}$, with reported hand dermatitis in the past 12 months; B, with palm dermatitis by examination; C, with dorsal hand dermatitis by examination; $\mathrm{D}$, with forearm dermatitis by examination. 
Table 3. Genotype frequency $(\%)$ of each genetic polymorphism

\begin{tabular}{llr}
\hline Gene & Genotype & $\%$ \\
\hline TNF $\alpha$-308 (successful in 147 samples) & GG & 84 \\
& GA & 16 \\
IL-4 -590 & AA & 0 \\
& CC & 65 \\
GST-T1 & CT & 33 \\
& TT & 2 \\
GST-M1 & Null & 59 \\
& Non-null & 41 \\
& Null & 52 \\
& Non-null & 48 \\
\hline
\end{tabular}

of personal protection. They also showed higher risk for chromate sensitization (Table 4) probably because of more skin contact with cement without adequate protection. Female cement workers were shown to have higher risk of nickel sensitization. Such difference in risk for nickel sensitization has been commonly reported, and probably related to earring use and other exposure routes in women (30).

When studying genetic predisposition to certain disease caused by an environmental agent, exposure level is important factor to be carefully controlled. Relationship between disease occurrence and exposure level should be established, and then genetic factor to be considered as an effect modifier. The cement workers who are responsible for interior finishing job such as selected in this population are a unique group for studying genotypic susceptibility to chromate. In Taiwan, addition of ferrous sulfate for reduction of soluble chromium and contact dermatitis (31) is not a common practice for the prevention of skin diseases in cement workers. Almost every male cement workers are highly exposed to cement and therefore

Table 4. Mutually adjusted odds ratios (95\% confidence intervals) of sex and each genetic polymorphism for skin sensitization to potassium dichromate ${ }^{\mathrm{a}}$

\begin{tabular}{llccl}
\hline & & \multicolumn{3}{c}{$\begin{array}{c}\text { Cases }(\%) \\
\text { Case } \\
\text { with positive }\end{array}$} \\
& & $\begin{array}{l}\text { numbers } \\
\text { reaction }\end{array}$ & Odds ratio \\
\hline Sex & Female & 62 & $3(4.8)$ & \\
& Male & 91 & $16(17.6)$ & $3.4(0.97-15.9)$ \\
TNF-308 & GG & 124 & $11(8.9)$ & \multirow{2}{*}{$3.9(1.14-13.2)$} \\
& GA & 23 & $6(26.1)$ & \\
IL-4 & CT+TT & 54 & $5(9.3)$ & NS \\
& CC & 99 & $14(14.1)$ & \\
GST-T1 & Non-null & 63 & $2(3.2)$ & $5.5(1.40-36.2)$ \\
& Null & 90 & $17(18.9)$ & 5.5 \\
GST-M1 & Non-null & 74 & $7(9.5)$ & NS \\
& Null & 79 & $12(15.2)$ &
\end{tabular}

NS, not significant.

${ }^{a}$ Odds ratios for sensitization to other patch agents were not related to any of these genotypes. sufficient levels of exposure to chromium in the cement. We can expect that those genetically prone to chromium sensitivity would have become sensitized. In the mean time, those non-sensitized were probably genetically non-prone to chromium sensitivity.

TNF- $\alpha$ plays an important role in the sensitization phase of allergic contact dermatitis $(32,33)$. Previous studies showed that when allergens activated the antigen-presenting cells (Langerhans cells) in the suprabasal cell layer, the Langerhans cells would produce IL-1 $\beta$, then stimulate epidermal keratinocytes to produce TNF- $\alpha$ to facilitate the following immunological process, which in term resulting in allergic contact dermatitis (34). TNF- $\alpha$ also plays an important role in the production of irritant contact dermatitis $(35,36)$. So, TNF- $\alpha$ plays a role in both irritant contact dermatitis and allergic contact dermatitis. Furthermore, it is proven that irritant contact dermatitis may promote the occurrence of allergic contact dermatitis, owing to the poor skin barrier caused by irritant contact dermatitis. The poor skin barrier may permit the allergens to penetrate the skin easily (37). It is known that cement workers are exposed to wet cement, that consists of $\mathrm{CaO}$ which, after dissolving in water, may produce $\mathrm{Ca}(\mathrm{OH})_{2}$ which is high in alkaline. The $\mathrm{pH}$ level may go up to 12-13 $(38,39)$. Cement workers are also prone to having abrasive and hydroscopic damage while working (40). As a result, irritant cement contact dermatitis occurs, which further facilitates the production of allergic cement contact dermatitis because of chromium hypersensitivity.

We found strong (with odds ratio of 4) association between TNF- $\alpha-308$ GA genotype and skin sensitization to chromate in cement workers. TNF2 allele created a promoter sequence which was a more potent transcriptional activator than the TNF1 allele $(41,42)$. Increased production of TNF- $\alpha$ was associated with TNF2 allele $(43,44)$. TNF- $\alpha-308$ GA genotype was associated with proneness to irritant contact dermatitis. Among volunteers receiving skin irritants sodium dodecyl sulfate and benzalkonium, those with TNF- $\alpha-308$ A allele were found to have lower threshold to developing irritation (45). Carriers of the TNF$\alpha-308 \mathrm{GA}$ and AA genotypes tended to be more common among polysensitized individuals, although not statistically significant (9). However, previous studies were not specific to chromium sensitivity. On the other hand, this study demonstrated clear association between TNF- $\alpha-308$ genotype and chromium sensitivity in highly exposed population, the cement workers.

IL4 plays a role in Th2 pathway, that may counter react with Th1 pathway, and may 
interfere with the occurrence of allergic contact dermatitis $(46,47)$. We did not find significant relationship between IL4 genotype and chromate allergy among our cement workers.

Glutathione-S-transferase (GST) plays an important role in skin metabolism of xenobiotics (48). The majority of skin allergens are redox inactive compounds, but some of them like $\mathrm{Cr}^{+6}$ can generate reactive oxygen species (ROS) through redox cycling or metabolic activation (49). There are 2 forms of chromium in cement, $\mathrm{Cr}^{+6}$ and $\mathrm{Cr}^{+3}$. The $\mathrm{Cr}^{+3}$ is water insoluble and penetrates the skin poorly. $\mathrm{Cr}^{+6}$ penetrates the skin more easily and is responsible for chromate hypersensitivity in cement workers. When $\mathrm{Cr}^{+6}$ penetrates the horny layer and enters the upper epidermis, $\mathrm{Cr}^{+6}$ will be reduced to $\mathrm{Cr}^{+3}(14,15)$. Then the $\mathrm{Cr}^{+3}$ can bind with skin proteins to form the complete antigen, which will be processed by Langerhans cells and initiate a type IV delayed hypersensitivity. During the reduction process of $\mathrm{Cr}^{+6}$ to $\mathrm{Cr}^{+3}$, there are many ROS generated, including hydroxyl radical, singlet oxygen, hydrogen peroxides (50). Oxidative stress has been linked to contact dermatitis, atopic dermatitis, and psoriasis $(51,52,53)$. The ROS can trigger redox-sensitive protein kinases and NF-KB transcription factors, and play a central and early role in the induction of inflammatory reaction $(54,55)$. It is also shown that ROS induce upregulation of dendritic cell surface markers which are involved in the interaction with $\mathrm{T}$ lymphocytes (56). Therefore, ROS may play an important role in the activation of Langerhans cells and the initiation of allergic contact dermatitis (57). GSTs are a large and diverse group of enzymes that can detoxify xenobiotics and endogenous toxicants. The members of the GST super-family, utilizing glutathione, can conjugate nonpolar or electrophilic compounds through nucleophilic reactions (58) and protect the cells from ROS (59). GST isoforms in mammalian cells include alpha, mu, kappa and theta class. The most important polymorphism encodes for a partial gene deletion in GST-M1 locus on chromosome 1p13.3. (GST-M1 null genotype) resulting in the complete absence of GST-M1 enzyme. The GST-T1 locus is on chromosome 22q11.2. The GST-T1 null genotype represents a partial gene deletion and is associated with the absence of functional activity of GST-T1 enzyme (59). Thus, poor GST-T1 activity may reduce the protection from ROS damage produced by the $\mathrm{Cr}^{+6}$ reduction process, and may contribute to the occurrence of allergic contact dermatitis. Why only GST-T1 but not GST-M1 affects susceptibility to chromate hypersensitivity is unknown, but might be related to different substrates of GST-T1 and
GST-M1. It is a common phenomenon that GST-T1 and GST-M1 have a different contribution to disease susceptibilities (60).

In conclusion, we found genetic predisposition of TNF- $\alpha-308$ GA genotype and GST-T1 null genotype to chromium sensitization among cement workers who were regularly exposed to chromium-containing cement.

\section{Acknowledgements}

This investigation was partially supported by grant \#IOSH84-M221 from Institute for Occupational Safety and Health, and partially supported by the Bureau of Labor Insurance, Executive Yuan of Taiwan, Republic of China.

\section{References}

1. Denton C R, Keenan R G, Birmingham D J. The chromium content of cement and its significance in cement dermatitis. J Invest Dermatol 1954: 23: 189-192.

2. Coenraads P J, Nater J P, Jansen H A, Lantinga H. Prevalence of eczema and other dermatoses of the hands and forearms in construction workers in the Netherlands. Clin Exp Dermatol 1984: 9: 149-158.

3. Rycroft R J G. Acute ulcerative contact dermatitis from ready-mixed cement. Clin Exp Dermatol 1980: 5: 245-247.

4. Fisher A A. Cement burns resulting in necrotic ulcers due to knelling. Cutis 1979: 23: 272-274.

5. Pirila V. On role of chrome and other trace elements in cement eczema. Acta Dermatol-Venereol (Stockh) 1954: 34: 136.

6. Calnan C D. Cement dermatitis. J Occup Med 1960: 2: $15-22$.

7. Kimber I, Cumberbatch M, Dearman R J, Bhushan M, Griffiths C E. Cytokines and chemokines in the initiation and regulation of epidermal Langerhans cell mobilization. Br J Dermatol 2000: 142: 401-412.

8. Howard T D, Meyers D A, Bleecker E R. Mapping susceptibility genes for asthma and allergy. J Allergy Clin Immunol 2000: 105: S477-S4481.

9. Westphal G A, Schnuch A, Moessner R, Konig I R, Kranke B, Hallier E, Ziegler A, Reich K. Cytokine gene polymorphisms in allergic contact dermatitis. Contact Dermatitis 2003: 48: 93-98.

10. Geha R S. Regulation of IgE synthesis in humans. J Allergy Clin Immunol 1992: 90: 143-150.

11. Rosenwaser L J, Klemm D J, Dresback J K et al. Promoter polymorphisms in the chromosome 5 gene cluster in asthma and atopy. Clin Exp Allergy 1995: 25: 74-78.

12. Zhu S, Chan-Yeung M, Becker A B et al. Polymorphisms of the IL-4, TNF- $\alpha$, and FceRI- $\beta$ genes and the risk of allergic disorders in at-risk infants. Am J Respir Crit Care Med 2000: 161: 1655-1659.

13. Rosenwasser L J, Borish L. Genetics of atopy and asthma: the rationale behind promoter-based candidate gene studies (IL-4 and IL-10). Am J Respir Crit Care Med 1997: 156: S152-S155.

14. Mali J W H, Van Kooten W J, Van Neer F C J, Spruit D. Quanitative aspects of chromium sensitization. Acta Dermatovenereol (Stockh) 1964: 44: 44-48.

15. Samitz M H, Katz S, Scheinern D M, Gross P R. Chromiumprotein interaction. Acta Derm Venereol (Stockh) 1969: 49: $142-146$. 
16. Shelly W B, Juhlin L. Langerhans cells form a reticuloepithelial trap for external contact antigens. Nature 1976: 261: 46-47.

17. Arslan P, Beltrame M, Tomasi A. Intrcellular chromium reduction. Biochimica et Biophysica Acta 1987: 931: 10-15.

18. Evans W E. Pharmacogenomics: translating functional genomics into rational therapeutics. Science 1999: 286: 487-491.

19. Seidegard J, Relling M V, Pero R W, Miller D G, Beattie E J. A glutathione transferase in human leukocytes as a marker for the susceptibility to lung cancer. Carcinogenesis 1986: 7: 751-753.

20. Pemble S, Schroder K R, Spencer S R, Meyer D J, Hallier E, Bolt H M, Ketterer B, Taylor J B. Human glutathione S-transferase theta (GSTT1): cDNA cloning and the characterization of a genetic polymorphism. Biochem J 1994: 300: 271-276.

21. Alexandrie A K, Sundberg M I, Seidegard J, Tornling G, Rannug A. Genetic susceptibility to lung cancer with special emphasis on CYP1A1 and GSTM1: a study on host factors in rlation to age at onset, gender and histological cancer types. Carcinogenesis 1994: 15: 1785-1790.

22. Anttila S, Hirvonen A, Husgafvel-Pursiainen K, Karjalainen A, Nurminen T, Vainio $H$. Combined effect of CYP1A1 inducibility and GSTM1 polymorphism on histological type of lung cancer. Carcinogenesis 1994: 15: 1133-1135.

23. d'Errico A, Taioli E, Chen X, Vineis P. Genetic metabolic polymorphisms and the risk of cancer: a review of the literature. Biomarker 1996: 1: 149-173.

24. Wang X, Zuckerman B, Pearson C et al. Maternal cigarette smoking, metabolic gene polymorphism, and infant birth weight. JAMA 2002: 287: 195-200.

25. Guo Y L, Wang B J, Wang J C, Yeh K C, Kao H H, Wang M T, Shih H C, Chen C J. Skin diseases in cement workers in Southern Taiwan. Contact Dermatitis 1999: 40: 1-7.

26. Wahlberg J E. Patch testing. In: Textbook of Contact Dermatitis, Rycroft R J G et al. (eds): Springer-Verlag, Berlin, 1992: pp. 239-268.

27. Walley A J, Cookson W O. Investigation of an interleukin-4 promoter polymorphism for associations with asthma and atopy. J Med Genet 1996: 33: 689-692.

28. Albuquerque R V, Hayden C M, Palmer L J et al. Association of polymorphisms within the tumour necrosis factor (TNF) genes and childhood asthma. Clin Exp Allergy 1998: 28: 578-584.

29. Arand M, Muhlbauer R, Hengstler J, Jager E, Fuchs J, Winkler L, Oesch F. A multiplex polymerase chain reaction protocol for the simultaneous analysis of the glutathione S-transferase GSTM1 and GSTT1 polymorphisms. Anal Biochem 1996: 236: 184-186.

30. Vahter M, Berglund M, Akesson A, Liden C. Metals and women's health. Environ Res 2002: 88: 144-155.

31. Avnstorp C. Follow-up of workers from the prefabricated concrete industry after the addition of ferrous sulphate to Danish cement. Contact Dermatitis 1989: 20: 365-371.

32. Enk A H, Angeloni V L, Udey M C, Katz S I. An essential role for Langerhans cell-derived IL-1 $\beta$ in the initiation of primary immune responses in skin. J Immunol 1993: 150: $3698-3704$

33. Steinman R M, Hoffman L, Pope M. Maturation and migration of cutaneous dendritic cells. J Invest Dermatol 1995: 105: $2 \mathrm{~S}-7 \mathrm{~S}$.

34. Wang B H, Amerio P, Sauder D N. Role of cytokines in epidermal Langerhans cell migration. J Leukoc Biol 1999: 66: 33-39.

35. Piguet P F, Grau G E, Hauser C, Vassalli P. Tumor necrosis factor is a critical mediator in hapten-induced irritant and contact hypersensitivity reactions. J Exp Med 1991: 173: 673-679.

36. Lisby S, Muller K M, Jongeneel C V, Saurat J H, Hauser C. Nickel and skin irritants up-regulate tumor necrosis factor-alpha mRNA in keratinocytes by different but potentially synergistic mechanisms. Int Immunol 1995: 7: 343-352.

37. Smith H R, Basketter D A, Mcfadden J P. Irritant dermatitis, irritancy, and it role in allergic contact dermatitis. Clincial and Experimental dermatology 2002: 27: 138-146.

38. Winder C, Carmody M. The dermal toxicity of cement. Toxicology and industrial health 2002: 18: 321-331.

39. Burrows D. Adverse chromate reactions on the skin. In: "Chromium: metabolism and toxicity", Burrow D (ed.): Boca Raton Florida, CRC press, 1983: pp. 137-163.

40. Avnstorp C. Cement eczema. An epidemiological intervention study. Acta Derm Venereol Suppl (Stockh) 1992: 179: 1-22.

41. Wilson A G, Symons J A, McDowell T L, McDevitt H O, Duff G W. Effects of a polymorphism in the human tumor necrosis factor alpha promoter on transcriptional activation. Proc Nat Acad Sci U S A 1997: 94: 3195-3199.

42. Kroeger K M, Carville K S, Abraham L J. The-308 tumor necrosis factor-alpha promoter polymorphism effects transcription. Mol Immunol 1997: 34: 391-399.

43. Bouma G, Crusius J B, Oudkerk Pool M et al. Secretion of tumour necrosis factor alpha and lymphotoxin alpha in relation to polymorphisms in the TNF genes and HLA-DR alleles. Relevance for inflammatory bowel disease. Scand J Immunol 1996: 43: 456-463.

44. Louis E, Franchimont D, Piron A et al. Tumour necrosis factor (TNF) gene polymorphism influences TNF-alpha production in lipopolysaccharide (LPS)-stimulated whole blood cell culture in healthy humans. Clin Exp Immunol 1998: 113: 401-406.

45. Allen M H, Wakelin S H, Holloway D, Lisby S, Baadsgaard O, Barker J N, McFadden J P. Association of TNFA gene polymorphism at position-308 with susceptibility to irritant contact dermatitis. Immunogenetics 2000: 51: 201-205.

46. Rowe A, Bunker C B. Interleukin-4 and the interleukin-4 receptor in allergic contact dermatitis. Contact Dermatitis 1998: 38: 36-39.

47. Asherson G L, Dieli F, Sireci G, Salerno A. Role of IL-4 in delayed type hypersensitivity. Clin Exp Immunol 1996: 103: $1-4$.

48. Seidegard J, Ekstrom G. The role of human glutathione transferases and epoxide hydrolases in the metabolism of xenobiotics. Environ Health Perspect 1997: 105: 791-799.

49. Fuchs J, Zollner T M, Kaufmann R, Podda M. Redoxmodulated pathways in inflammatory skin diseases. Free Radic Biol Med 2001: 30: 337-353.

50. Standeven A M, Wetterhahn K E. Is There a Role for Reactive Oxygen Species in the Mechanism of Chromium (VI) Carcinogenesis? Chem Res Toxicol 1991: 4: 616-625.

51. Miyachi Y, Uchida K, Komura J, Asada Y, Niwa Y. Auto oxidative damage in cement dermatitis. Arch Dermatol Res 1985: 277: 288-292.

52. Wolber R, Staeb F, Abeck D, Bleck O, Schreiner V, Untiedt S, Sauermann G, Hoppe U. Antioxidant status and role of oxidative stress in atopic dermaitits. J Invest Dermatol 1996: 106: 888 .

53. Pereira P, Rocha R L, Santos-Silva A, Figueiredo A, Ferra M I A, Quintanilha A, Teixeira F. Leukocyte activation and oxidative stress in psoriasis. Br J Pharmacol 1999: 127: 83 .

54. Bauerle P A, Henkel T. Function and activation of NFkB in the immune system. Annu Rev Immunol 1994: 12: 141-179.

55. Sen C K, Packer L. Antioxidant and redox regulation of gene transcription. FASEB J 1996: 10: 709-720.

56. Rutault K, Alderman C, Chain B M, Katz D R. Reactive oxygen species activate human peripheral blood dendritic cells. Free Radic Biol Med 1999: 26: 232-238.

57. Sharkey P, Eedy D J, Burrows D, McCaigue M D, Bell A L. A possible role for superoxide production in the pathogenesis 
of contact dermatitis. Acta Derm Venereol (Stockh) 1991: 71: $156-159$.

58. Hayes J D, Strange R C. Glutathione S-transferase polymorphisms and their biological consequences. Pharmacology 2000: 61: 154-166.

59. Holla L I, Stejskalova A, Vasku A. Polymorphisms of the GSTM1 and GSTT1 genes in patients with allergic diseases in the Czech population. Allergy 2006: 61: 265-267.

60. Strange R C, Lear J T, Fryer A A. Glutathione S-transferase polymorphisms: influence on susceptibility to cancer. Chem Biol Interact 1998: 111-112: 351-364.
Address:

Professor Dr Yue-Liang Guo

Department of Environmental and Occupational Medicine National Taiwan University (NTU) Medical Center

National Taiwan University (NTU) Hospital

17 Syujhou Road

Taipei 106

Taiwan

Tel: (886)2 33228216

Fax: (886)2-3322-8214

e-mail: leonguo@ha.mc.ntu.edu.tw 